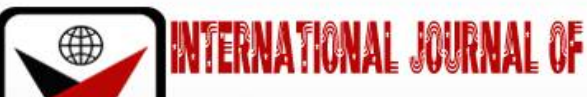

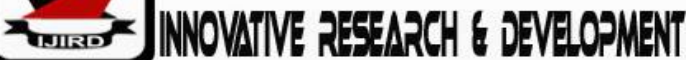

ISSN 2278-0211 (Online)

\section{Approaches in Creative Writing Pedagogy in English in Upper Primary Classes in Kenya}

Sophie Ahono Maninji
Ph.D. Student, Department of Educational Communication Technology \& Curriculum Studies,
Maseno University, Maseno, Kenya
Dr. Doreen J. Lugendo
Lecturer, Department of Educational Communication Technology \& Curriculum Studies,
Maseno University, Maseno, Kenya
Dr. Joseph A. Rabari
Lecturer, Department of Educational Communication Technology \& Curriculum Studies,
Maseno University, Maseno, Kenya

\begin{abstract}
:
Creative Writing (CW) is a highly complex skill especially to learners who are non-native speakers of English. In Kenya, English is taught as a second language (L2) and is both an examinable subject and a language of instruction. However, over $62 \%$ of learners lack basic writing skills and fail to achieve writing competence at the end of primary course; Class 8. In Vihiga County, primary schools have persistently underperformed in CW with more than (70\%) of Class 8 learners scoring below the average mean mark which is measured through imaginative composition writing. Despite the complexity of $\mathrm{CW}$ and underperformance, only a few studies are available and those conducted in Kenya have established that $60 \%$ of teachers find it difficult to teach CW while $75 \%$ of learners find it boring. These have implications for pedagogy and students' writing enthusiasm. The objective of the study was to explore the use of process, product and genre pedagogic approaches and their effectiveness in the development of CW skills. Archer's theory of reflexivity which views writing as internal and external conversations and addresses the concerns of the individual and the social structures or 'expected' ways of acting in a particular context guided the study. This involves deliberating certain courses of action, deciding what might be feasible at the time of writing situation and then suggesting a solution to a CW difficulty. The study used qualitative exploratory research design and the study was conducted in Vihiga County. The data collection tools were Lesson Observation Schedule and Interview Schedule whose validity and reliability were tested through triangulation. From Class 6-8, 30 lessons in 10 purposively selected schools were observed and 30 teachers whose lessons had been observed were interviewed. Data were analyzed thematically through transcription, coding and identification of themes. The key finding was: inappropriate use of CW approaches due to teachers' knowledge gaps on CW pedagogical approaches. The study recommended that teachers of English use product, process and genre approaches appropriately in CW pedagogy, and the Ministry of Education in-servicing of teachers on the CW approaches. The results are useful to teachers of English and Teacher Training Institutions.
\end{abstract}

Keywords: Approaches, creative writing and upper primary learners

\section{Introduction}

In upper primary classrooms in Kenya, Creative Writing (CW) typically refers to imaginative composition writing. Imaginative writing is the use of written language to conceptualize, explore and record experiences in such a way as to create a unique symbolization of it (Khan, 2011).One of the objectives of the primary English curriculum in Kenya is for all pupils to acquire sufficient command of English in spoken and written forms to enable them to communicate fluently, independently and accurately in everyday life, (KIE, 2002; 2004). Besides, the aim of writing in upper primary schools in Kenya is to enable learners to write a continuous prose of narrative, a simple letter, a short dialogue and a few other types of prose that are accurate, fluent, relevant and imaginatively original (KIE, 2006). Despite the aim and objective of writing in upper primary classes, Sure and Ogechi (2009) found out that by Class 8, in Kenya, students are unable to communicate effectively in English. Considering that English is the language of instruction, it significantly impacts students' success in other areas (Kioko \& Muthwii, 2001). English composition is not a multiple choice test and calls for a candidate's creativity in writing. Learners are expected to write a composition which carries $40 \%$ of the total Kenya Certificate of Primary Education (KCPE) score. They are expected to creatively express themselves using their imagination and figurative language (Mwangi, 2016). However, learners underperform in CW because they face great difficulty in expressing themselves in simple English during imaginative writing (Kalemesi, 2016).Despite the pivotal role attached to composition 
writing in the Kenyan curriculum, Kenya National Examination Council (KNEC)reveals that primary schools learners lack basic writing skills (KNEC Newsletter 2010, 2011, 2012, 2013, 2014).

Pedagogical approaches are important variables in effective teaching and enhancement of CW as they enlighten learners on CW rubric and are among the factors responsible for unsatisfactory performance in CW. However, few studies have been conducted on CW pedagogical approaches and their effectiveness in teaching CW. More so, many of these studies were conducted in Western socio-cultural environment with different pedagogical contexts thus, some of the approaches require adaptation to Kenyan contextual realities for effective utilization. In addition, English language teachers are usually trained in Western approaches and methods of language teaching, some of which need adaptation to the (L2) classes (Ong'ondo, 2009). Few studies have been conducted on CW in Vihiga County primary schools. No study has focused on CW pedagogical approaches and their effectiveness in the development of CW skills in upper primary classes. The performance of CW in Vihiga County is low; with a deviation of 2 in composition mean grades, compared to their neighboring counties in Nyanza region although both counties have trained teachers and similar infrastructure and teaching resources hence the need to interrogate CW pedagogy.

\subsection{Importance of Writing Skills}

Despite the writing complexities and difficulties, CW is considered the most important language skill that students require for their personal development and academic success (Mukulu et al. 2006). Rao (2007; 2018) points out that writing strengthen students' learning, thinking and reflect on their academic performance. Affirming Rao's position is Ahmed (2010) who notes that competence in writing helps students perform well in all their academic programmes. Moreover, being proficient in writing in English enables students to be professionals and action researchers in the future. Learners enjoy self- expression and learn to convey needs in messages and other communication from within and as they get grounded in their writing skills, they become more self-reliant (Durga \&. Rao, 2018). Furthermore, Durga and Rao (2018) argue that naturally, students with good writing skills are always successful at expressing their ideas and reaching their goals. Therefore, learners should develop the writing skills for their multiple benefits and success in life.

\subsection{CW Approaches}

Utilization of appropriate writing approach results in good, well written, coherent and balanced compositions (Adas \& Bakir, 2013) whilelack of suitable learning approaches in writing results in low motivation for students (Lo \& Hyland, 2007). Therefore, appropriate CW approaches should be grasped from lower educational level, since student writing enthusiasm depends on writing approach employed (Adas \& Bakir, 2013). To solve the problem of underperformance in CW, Lipstein and Renninger (2007) suggested the need for a better understanding of how to develop a suitable learning approach or authoring tool to enhance students' writing. This premise informed the study to trace CW pedagogy from Class 6, 7 and 8 to ascertain the effectiveness of CW approaches in upper primary classes.

Teaching writing has seen numerous approaches and methods crossing its way since the early eighties. The focus has shifted from sentence structure and grammar drills to usage and text organization as argued by Richards (2005) that from the beginning of the $19^{\text {th }}$ century, different language teaching approaches have been applied and that teachers and linguists have periodically sought to improve language teaching methods. As a result of different changes in viewpoints toward writing practice and its important role for second language learning, various pedagogical approaches have been proposed by different researchers (Matsuda, 2003). Of all the approaches proposed, Eliwarti and Maar of (2014) argue that there are three popular and holistic approaches that encompass aspects of accuracy, fluency and creativity drawn from the three approaches to teaching writing, they are: Product-based approach, Process-based approach, and Genrebased approach respectively. In addition, the synthesis of these three approaches improves CW. Fluency, accuracy and creativity form the three broader scoring areas in CW for the Kenyan upper primary learner.

These three dimensions of perceiving CW are embedded in the product, process and genre approaches to writing. Regardless of the shift and changes in viewpoints towards writing, CW still poses a challenge to L2 learners and many teachers of English are not confident to teach CW. Adas and Bakir (2013) argues that, achieving good composition is a complex and difficult task for both native speakers and non-native speakers of English. Nevertheless, it will be beneficial for teachers to have a systematic understanding of different approaches to teaching writing. Considering Ochako (2019) in her study on 'Approaches of Teaching Imaginative Composition,' among other recommendations that the study made was organizing for more workshops and giving updates on the teaching approaches. The importance of workshops and updates on approaches are advocated for by Ochako (2019) who further argues that the instructional approaches are important variables in effective teaching to enhance learning of imaginative writing. The preceding researcher focused on the process approach alone but the present study focused on product, process and genre approaches because Eliwarti and Maarof (2014) and Ibrahim (2013), argue that the synthesis of these three approaches improves CW competence because they develop accuracy, fluency and creativity which are important to CW.

A marriage of the best aspects of appropriate approaches may be a way to limit the pitfalls of individual approaches is advocated for by Hasan and Akhand (2011) who provided instructional insights on implementing different writing approaches to help students achieve the desired writing goals in each stage of writing and to eventually produce an excellent product. Similarly, Reem, Wafa'a, Danyah \& Nadia (2018) examined the effects of different approaches to teaching writing in English as a Foreign Language/English as a Second Language (EFL/ESL) students' writing performance. The results revealed that implementing a new approach to writing instruction that combines different approaches was effective. A study by Badger and White (2000) based on the Process Genre Approach theoretical model for teaching writing skills recognized that effective teaching approach for writing needs to integrate the insights from product, process and genre approaches. Tangpermpoon (2008) claims that by integrating the three approaches, the strengths of 
each approach can successfully complement each other and help teachers to develop students' written competence by providing appropriate input of knowledge and skills in the writing process.

It is further highlighted by Gathumbi and Masembe (2005) that the integrated approach to language teaching aims at maximizing meaningful communication and classroom interactions in meaningful situations. It fosters holistic learning such as sharing of information, experiences and development of values. It gives language skills their most meaningful, practical and relevant application, while at the same time giving the student the necessary tools for full learning. With the amalgamation of the three approaches being seen as a solution to poor CW skills as they focus on the form, the writer and the reader which are instrumental in CW, it's important to note that these studies were conducted in Western countries which have different socio economic and socio cultural dispositions. Of all the studies that have been conducted in Kenya on CW, a majority of them focus on secondary schools. None of the studies conducted in primary schools on CW looked into the pedagogical approaches in CW especially these three principal approaches; process, product and the genre approach hence a need for such a study in Vihiga County in Kenya due to its persistent underperformance in CW.

\section{Research Methodology}

The objective of the present study was fulfilled through a qualitative exploratory research design which, according to Burns and Groove (2001), is conducted to gain new insights, discover new ideas, and for increasing knowledge of the phenomenon. The study explored the CW approaches upper primary teachers employ during their writing lessons in order to gain insights into the effectiveness of the approaches employed in CW pedagogy and suggested ways of improving CW in Vihiga County primary schools. The study was carried out in Vihiga County in the Western Region of Kenya. The choice of Vihiga County was influenced by the fact that the public primary schools in this area have persistently underperformed in English composition and also its rural setup that can exemplify practice as opposed to the urban setups which are well resourced and are deemed to have L2 competent learners. Stratified purposive sampling was employed to select teachers of English from the purposively selected schools from class 6, 7 and 8 for lesson observation during their teaching of CW. Teachers whose lessons had been observed were interviewed by the researcher in order to help the researcher corroborate the data that had been collected. Stratified purposive technique was appropriate for the present study because it focuses on characteristics of particular subgroups of interest. The sample was stratified based on the level of upper primary classes hence the Class 6, 7 and 8 that were involved in the study.

All the 30 teachers of English from the 10 purposively selected schools were interviewed and 30 CW lessons; one from each class in the 10 selected schools was observed during CW instruction. The 30 teachers interviewed and the 30 lessons observed were informed by Guest, Bunce, and Johnson (2006) who advocate for saturation, the point at which a researcher no longer receives any new information or insight into the phenomenon of study from each subsequent interview or observation, and it often occurs at around 12 for a homogeneous participant group. They further argue that a minimum of 15 for most qualitative interview studies works very well when the participants are homogeneous. In this study, homogeneity of participants involved teachers of English in upper primary classes for interview and observation of upper primary CW lessons. For a particular group, saturation often occurs between 12 and 15. However, Nastasi (2005) recommends a sample size of 30 for in-depth interview thus the interviewing of the 30 teachers of English in upper primary classes. Oral semi structured interview schedules were administered to class 6, 7 and 8 teachers of English on the CW approaches and their effectiveness in developing CW skills because interview schedules are a feasible and adaptable way of finding out information (Cresswell , 2009). For classroom observation, according to Wragg (2011),they are used in a study and should suit its purposes. Therefore, the classroom observation methods and procedures were carried out in line with the research's main purpose of establishing the approaches and current CW practice in Kenyan upper primary classrooms.

Stake (2005) explains that to give quality, credibility, and trustworthiness to a qualitative research, certain methods are used which include: triangulation, saturation, member checking and self-disclosure (Reflexivity). In qualitative research, validity entails the researcher checking for the accuracy of the findings by employing certain procedures, while reliability indicates that the researcher's approach is consistent (Creswell, 2009). To ensure that the findings in this research are accurate and credible, a number of measures were taken. Validity strategies such as data triangulation and the use of thick and rich descriptions of the procedures and findings were used. By converging data from the two sources, conclusions were drawn from various angles making the research findings trustworthy. Secondly, the researcher involved peers and experienced researchers in reviewing key concepts, methodology and analysis and to help check the credibility of the research rationale, research process and report as suggested in research literature (Stake, 2006).

Regarding reliability, Richards (2009) explains that 'dependability in qualitative research involves an interrogation of the context and the methods used to derive the data' (p159). Yin (2003) suggests that one way of enhancing dependability is to make clear and detailed descriptions of the steps followed in the study. To ensure dependability in this study, care was taken to make a thick description of the entire research process in a manner that makes it possible to carry out a similar study in another context, if necessary (Ponterotto, 2006).In the process of data generation, the researcher accumulated a data set consisting of interview and observation notes. The researcher utilized thematic analysis. Braun and Clarke (2006) explain that: Thematic analysis is a method for identifying, analysing, and reporting patterns (themes) within data. It minimally organizes and describes your data set in (rich) detail. To ensure consistency in approach during the study, the exploratory study procedures was documented and applied consistently in the data collection phase by immediately describing in detail the opinions and feelings and the behavior captured during interviews and classroom interactions; then transcribing the data. The same procedure was used for all the ten classroom observations. Once classroom observation data was transcribed from recorded classroom interactions and checked for 
accuracy to make sure that it does not contain mistakes. Measures were also taken in thematically coding to ensure that there were no drifts in the definitions of codes or shifts in the meaning of codes during the process of coding.

Data analysis was achieved using content and thematic analysis and discourse analysis. Interview data was subjected to narrative while classroom observation data was analysed using discourse analysis. Teacher-learner interactions from the classroom observation were used to corroborate the data from the interviews with teachers about the methods they employ to teach CW. Content analysis was used where qualitative data had been collected using documents. Narrative approach was used to present data from teacher interviews. In terms of ethics, according to Mason (2002), the researcher observed truthfulness and all participants were given accurate and detailed information about the research, their express consent, confidentiality and anonymity were assured, any sort of harm was avoided and the researcher show appreciation of the participants' support in any appropriate manner (Cohen et al., 2007). The researcher then wrote a detailed report using qualitative data that was thematically, interpreted and described in subsections under the three approaches in focus.

\section{Results and Discussions}

Data from classrooms revealed ineffective utilization of the product, process and genre approach due to the piecemeal approach in the use of CW approaches. Throughout the class 6, 7 and 8 lessons observed, learners listened to explanations by the teacher, wrote down samples of composition in their exercise books as directed by the teacher and responded to questions where they could. None of the approaches employed fully utilized the steps in the approaches. Out of the 10 Class 8lessons observed, 3 conformed to product approach, 5 of them conformed to process approach, 1 to genre approach and other 1 conformed to a mixed approach. In Class 7,5 lessons leaned towards a product approach, 3 towards process approach, 1 towards genre approach and the other 1 towards mixed approach. In Class 6, aspects of product approach dominated the lessons with 7 lessons leaning towards product approach and 2 towards process approach. One lesson in Class 6 was not captured because the teacher taught friendly letters which was outside the scope of the present study. Class 6 neither utilized genre nor mixed approach but mainly used product approach. The process approach was mainly employed in CW teaching in class 7 and 8.

\subsection{The Product-oriented Approach}

For the product oriented approach, the instruction proceeds from the perspective that one type of writing was suitable for all the learners (Khan, 2012). Most of the time, when learners were involved in the lesson, they gave chorus answers which makes it difficult to attend to individual needs. Learners were very passive, examples were inadequately utilized and the only chance they got to speak was by affirming the teacher's position by a 'yes' response. In this approach, the focus of instruction was on students finished products. The learners were to write a composition based on the title given and present their work for marking (Groanwegan; 2008). The various features of an imaginative composition were described in general terms, for example, introduction, body and conclusion. It was not mentioned that different kinds of writing were required for different situations or different disciplines (Ibrahim; 2013) as the genre approach would.

A key aspect utilized the product approach in all the lessons observed was the utilization of models. The product oriented approach focuses on grammatical correctness and adherence to given models or guidelines (Tribble, 2009). However, imitating models inhibits writers rather than liberating them by giving them little or no opportunity for the learner to add any thoughts or ideas of their own (Brown, 2001). The room for learner creativity is constrained and the inevitable consequence is that little attention is paid to the ideas and meaning of students writing, what it communicates to the reader, the purpose and the audience (Groanwegen, 2008).Learners simply read a model and were asked to write a composition which was not even related to the model they had read. This failed the test of a well utilized product approach in writing because according to Rao (2016), product approach has four stages namely: familiarization, controlled writing, guided writing and free writing - all of which were missing in all the product oriented lesson episodes observed. When these teachers were asked why the used the product approach and whether it was effective in developing CW skills, they posited, 'We use product approach because it is effective in helping the learner build vocabulary. Besides, learners have a model of how to write which makes learners less apprehensive and importantly, it develops fluency.'

However, the teachers' assertions were at variance with classroom observation data because some of the models failed to achieve their purpose. Imitation which is key to product approach was not emulated. Learners simply read a model and were asked to write a composition which in some instances, was not related to the model they had read. In addition, a well utilized product approach in writing according to Rao (2016) has four stages namely: familiarization, controlled writing, guided writing and free writing - all of which were missing in all the product oriented lesson episodes observed. Therefore, in terms of the effectiveness of product oriented approach in teaching CW, the observation schedule results were at variance with the interview schedule results. While results from the classroom observation depicted ineffectiveness utilization of the approach in teaching CW in upper primary classrooms, the teachers interviewed felt the approach was effective.

\subsection{The Process-oriented Approach}

A close scrutiny of the presentation of the lessons under the process approach from Class 6 to 8 revealed that teachers adopted only brainstorming and organization of the information, collaborative learning and editing. Brainstorming and organization of the information was very helpful as it ensured learners had what to write (content) and in an orderly way. However, good writers plan and revise, rearrange and delete text, re-reading and producing multiple drafts before they produce their finished document and this is what a process writing approach is about (Stanley 2007). According to Williams (2003), writers may find it necessary and useful to write down their important ideas in outline 
form, starting with small ideas and moving to more general ones- an aspect that two of the teachers under process approach utilized. Generally under process approach, the only item of this approach that teachers emphasized on was generating a story using the $4 \mathrm{Ws}$ and $\mathrm{H}$ questions while the product approach employed was concerned with the learner producing a grammatically correct script and the use of model compositions.

The stages that were not effectively handled yet they are important stages are editing and revising. The main concern of the revising stage is to complete the content correctly, whereas correcting grammatical and spelling mistakes can be done during the editing stage (Tribble, 2009). In the revising stage learners should carry out activities such as deleting unnecessary sentences and moving certain words or paragraphs forward or backward (Williams, 2003; Hedge, 2000). All the teachers included in the study admitted they failed to guide learners through the revising stage because of time constraint thus the common phrase, 'proof read your work to avoid silly mistakes.' Editing is the last stage of the process approach to writing. This stage concentrates on linguistic accuracy: grammar, spelling and punctuation (Durga \& Rao, 2018). Hewings and Curry (2003) state that the editing stage involves checking references and formatting the students' writing. In this stage students may employ various strategies to correct their mistakes, such as working in pairs or in groups, and use any available resources such as textbooks, dictionaries and computers (Hewings \& Curry, 2003). Out of the eight stages in process approach, only planning seems to be attempted in the lessons observed. However, from the preceding discussion, if these stages are followed adequately and appropriately, they will go a long way in helping upper primary learners to be good creative writers.

\subsection{The Genre Approach}

The genre approach to writing supports students' writing with generalized, systematic guiding principles about how to produce meaningful passages for example, in private stories. Cowley (2004) believes by approaching CW via genre, students' interest and motivation is enhanced. More so, genre approach requires samples of a specific genre to be introduced, and some distinctive characteristics of the given genre be pointed out so that learners notice specific configurations of that genre thus making it resemble the product approach in that a model text is analyzed on the basis of grammatical and text features. This is followed by guided writing in a joint construction stage before a final, free-writing stage (Badger \& White, 2000). The guided writing grounds the learner in the CW tenets being tackles as opposed to product approach where the learners have to imitate the model. Next, students attempt to produce the first draft through imitating the given genre hence making learners less apprehensive during composition writing. However, in the application of genre approach in teaching, it also has been criticized for stifling creativity by imposing models on students (Hyland, 2008) , but, Hyland further clarifies that the genre does not dictate that the students neither write in a certain way nor determine what to write, it enables choices to be made to create meaning. This argument allows the teacher to manipulate classroom interactions and teach learners how to write creatively but the students are automatically guided very much to imitate since they are only provided with very little practice on developing linguistic skills. In accordance with this, Badger and White (2000) argue that the negative side of genre approaches is that they undervalue the skills needed to produce a text and see learners as largely passive; this passivity was pronounced in the lessons observed but it is a limitation that process approach to writing takes care of when effectively. Besides the use of a model, another aspect of genre approach displayed in the lesson was the mention of tenets that make creative writing interesting. This aimed at tackling the peculiarity of CW from other pieces of writing; a major aspect of genre approach. Just like the preceding approaches, genre approach was not effectively utilized since the teachers superficially mentioned the aspects of the approach without proper guidance to the learner.

\subsection{The Mixed Approach}

The mixed approach encouraged collaborative and highly interactive lessons. The teacher gave relevant examples and allowed learners to make their contribution individually and in groups. An approach that is covered in the process and genre approaches to CW. The limitations of process approach being covered by genre approach and vice versa. The class was generally interactive and learners keenly followed the lesson. This exemplary instruction is a clear indicator that the teacher's instruction and the approach to CW pedagogy. The process - genre approach to teaching writing was proposed to overcome the pedagogical shortcomings of both the genre and the process approaches in developing L2 students' writing skills (Badger \& White, 2000; Hasan \& Akhand, 2010). These researchers further observed that process genre approach is a hybrid; the combination of the process models and the genre theories which takes into consideration the development of the writing skills and the conventions, concept of which not only draws from the genre approaches such as knowledge of context, the purpose of writing and certain text features but also retains the process philosophy such as writing skills development and learners' response.

For the mixed approach, which was an emerging theme, the Class 8 lesson extract was similar to the Class 7 lesson episode because the same teacher taught English in Class 7 and 8 implying that some teachers have the skills of developing CW and could mentor their peers on pedagogic strategies that work. The mixed approach enhanced the development of CW skills, was very interactive and learners produced better creatively written texts compared to the classes which singly utilized either of the three approaches. Many researchers (Andrew \& Romova, 2012; Yasuda, 2011; Cheng, 2006; Kim \& Kim, 2005) who successfully adapted genre-based teaching in L2 classrooms argued that the fundamental issues underlying the genre-based approach can be improved by incorporating process-focused instruction.

In a follow up interview with teachers whose lessons had been observed, the researcher wanted to corroborate classroom data with interview data and seek clarification. From the teachers' narration, they partially employed aspects of product, process and genre approaches. The teachers who used process approach argued that through corrections, the teacher gives the rubrics of good imaginative composition and helps learners improve in subsequent compositions as they 
know the rubrics and it gives learners confidence since they are aware of the stages and know what to do under every stage. The genre approach was utilized because it is interactive, learners develop creativity and learners are confident when writing. The mixed approach which was the best in developing CW skills though barely used built learners creativity and imagination, contributed to fluency and coherence and made learners confident as they knew what to do. Therefore, the three approaches are rich in developing CW skills when properly utilized.

\section{Conclusions}

On the basis of the findings of the study, the following conclusions were made:

- Teachers in Vihiga County rarely used CW approaches effectively to teach composition due to inadequate time and limited CW resources, inadequate knowledge in CW approaches.

- Little attention given to CW during both pre-service and in-service training. Therefore, the use of appropriate approaches can develop various aspects of CW thus significant improvement can be realized.

Appropriate approaches help learners gain confidence during CW since they know what to write and how to write. Teachers in upper primary school should therefore be encouraged to use product, process, genre and a combination of the three approaches to improve the teaching of composition because they enhance creativity of thought and language use, accuracy in grammar and fluency in logic and flow of ideas which are key areas in CW.

\section{Recommendations}

- Teachers of English should learn and embrace the use of product, process and genre approaches in the teaching of composition. This too should be adopted and standardized by the Kenya Institute of Curriculum Development and to both teachers and learners relevant CW materials.

- The Ministry of Education in Kenya to organize for teachers of English regular training and refresher courses on the teaching English composition writing using product, process and genre approaches of writing.

- A review of the pre-service and in-service English courses with attention directed to CW.

\section{References}

i. Adas, D., \&, A. Bakir (2013). Writing Difficulties and New Solutions: Blended learning as an Approach to Improve Writing Abilities. International Journal of Humanities and Social Science. Vol.3:254-266.

ii. Ahmed, A. (2010).Students' problems with cohesion and coherence in EFL essay writing in Egypt: Different perspectives. Literacy Information and Computer Education Journal (LICEJ), Vol.1:219-221.

iii. Andrew, M. and Romova, Z. (2012) Genre, discourse and imagined communities; The learning gains of academic writing learners. Journal of Academic Language\& Learning. 6(1):77-78

iv. Badger, R., \& White, G. (2000). Product, process and genre: Approaches to writing in EAP [Electronic version]. ELT Journal, 54(2), 153-160.

v. Braun, V. and V. Clarke (2006). Using thematic analysis in Psychology. Qualitative Research in Psychology, 3,77101.

vi. Brown, H. D. (2001). Teaching by principles: An interactive approach to language pedagogy (2nd ed.). New York: Addison Wesley Longman.

vii. Burns, N. \& Groves, K. (2001) The Practice of Nursing Research: Conduct, Critique \& Utilization, 261-285, Elsevier Science Publishers.

viii. Cheng, A. (2006) Understanding learners and learning $n$ ESP genre-based writing instruction. English for Specific Purpose. 25(1): 76-89.

ix. Clarke, V. (2006). Using thematic analysis in Psychology. Qualitative Research in Psychology, 3,77-101.

X. Cohen, L.et al. (2009) Research Methods in Education (5th ed.). London: Routledge Falmer. Composition skills in the primary school. Comprehension'. TESOL Quarterly 21, 4, 737-758.

xi. $\quad$ Cowley, S. (2004). Getting the Buggers to Write. London: Continuum.

xii. Creswell, J. W. (2009). Research Design: Qualitative, Quantitative, and Mixed Methods

xiii. Durga, S \&. Rao, C. (2018) Developing Students' Writing Skills in English - A Process Approach

ISSN: 2456Research Gate Journal Issue 6, Vol. 2.

xiv. Eliwarti, E. \& Maarof, N. (2014). The effects of types of writing approaches on EFL students' writing performance. In SELT (pp. 112-119). Padang: SELT.

xv. Gathumbi, A. W. and S. C. Masembe (2005). Principles and techniques in language teaching. Nairobi: Jomo Kenyatta foundation.

xvi. Gathumbi, A.W \& Musembe, C.M. (2008) Principles and Techniques in Language Teaching. Nairobi: Jomo Kenyatta foundation.

xvii. Gillespie, A. and Graham, S. (2010) Evidence-based practices for teaching writing. Johns Hopkins University School of Education: New Horizon for learning.

http://education.jhu.edu/newhorizons/Better/articles/Winter2011.html

xviii. Groenwegen, T. (2008) Benchmarks for English language, Education Practioners, Nairobi: Phoenix publishers.

xix. Guest, G., Bunce, A., \& Johnson, L. (2006). How many interviews are enough? An experiment with data saturation and variability. Field Methods, 18(1), 24. doi: 10.1177/1525822X05279903

xx. Harmer, Jeremy. 2007. ThePractice of English Language Teaching. Fourth Edition. China: Pearson, Longman.

xxi. Hasan, M. K. \& Akhand, M.M. 2010. Approaches to Writing in EFL/ESL Context: Balancing Product and Process in Writing Class at Tertiary Level. Journal of NELTA, 15: 77-88 
xxii. Hasan, M. K \& Akhand, M. M. 2011. Approaches to Writing in EFL/ESL Context: Balancing Product and Process in Writing Class at Tertiary Level. Journal of NELTA Vol. 15 No. 1 2.https://www.researchgate.net/publication/325489625

xxiii. Hewings, D. \& Curry, M.J (2003) Approaches to Teaching Writing. In Coffin,C; Curry, M. J;Goodman, S; Hewings, A;Lillies,T. M \&Swann,J. Teaching Academic Writing; A toolkit for higher education. London. Routledge.

xxiv. Ibrahim, I. E. (2013) The Effect of the Genre-Based Approach to Teaching Writing on the EFL Al-Azhr Secondary Students' Writing Skills and their attitudes towards writing. Unpublished PhD Thesis. Mansoura University. Mansoura.

xxv. Kalemesi, J.P. (2016)The Role of Pictures in Teaching English Composition Writingin Upper Primary School in Emuhaya Sub-County, Unpublished Masters Thesis, Kenyatta University, Kenya.

xxvi. Kenya Institute of Education (2002). Secondary Education Syllabus. Vol. 1. Nairobi: Jomo Kenyatta Foundation.

xxvii. Kenya Institute of Education (2004) Revised Secondary Education Syllabus. Nairobi: KIE. Language writing, Vol. $12(1), 65-83$.

xxviii. Kenya Institute of Education (2006). Secondary English teachers' handbook. Nairobi: Kenya Literature Bureau. Kenya.

xxix. Kenya National Examination Council. (2010). Report on candidates performance in Kenya certificate of secondary education. Nairobi: KNEC.

xxx. Kenya National Examination Council. (2011). Report on candidates performance in Kenya certificate of secondary education. Nairobi: KNEC.

xxxi. Kenya National Examination Council. (2012). Report on candidates performance in Kenya certificate of secondary education. Nairobi: KNEC.

xxxii. Kenya National Examination Council. (2013). Report on candidates performance in Kenya certificate of secondary education. Nairobi: KNEC.

xxxiii. Kenya National Examination Council. (2014). Report on candidates performance in Kenya certificate of secondary education. Nairobi: KNEC.

xxxiv. Khan, I. (2012). English Teachers' Perception about Creativity and Teaching Creative Writing in Pakistan. American International Journal of Contemporary Research.

xxxv. Kim, Y.,\& Kim, J. (2005).Teaching Korean University writing class: Balancing the process and the genre approach. Asian EFL Journal Quarterly, Vol.7, 69-90.

xxxvi. Kioko, A. N. \& Muthwii, M. J. (2001).The Demands of a Changing Society: English in Education in Kenya Today. Language, Culture and Curriculum, 14(3), 201-213.

xxxvii. Lipstein.L.L; \&Renninger, K.A. (2007). Interest for Writing; How teachers make a difference. English Journal, Vol, 96,79-85.

xxxviii. Lo, J., \& Hyland, F. (2007). Enhancing students' engagement and motivation in writing: The case of primary students in Hong Kong. Journal of Second Language Writing, 16(4), 219-237.

xxxix. Mason, J. (2002). Qualitative researching (2nd ed.). London: Sage Publications.

xl. Matsuda, P. K. (2003). Process and post-process: A discursive history. Journal of Second Language.

xli. Mukulu, E.,Indangasi, H., Mwangi, P., Gecaga,C. \& Okanga, N. (2006.) KCSE Revision English. Nairobi.Kenya Literature Bureau.

xlii. Mwangi, L. (2016). Effect of Dramatization on Learner Achievement in Learning English Language in Public Secondary Schools in Meru County, Kenya. Unpublished master's thesis, University of Nairobi, Nairobi, Kenya.

xliii. Nastasi, B. (2005). Contributions of Qualitative Research to the Validity of Intervention Research.Journal of School of Psychology, Vol.43:177-195.

xliv. Ochako, I. K., Okwako, E., \& Okoth, T. (2019). Approaches Teachers use in Teaching Imaginative Writing - a case of Secondary School Teachers in Kakamega Central Sub-County, Kenya. International Journal of Academic Research Business and Social Sciences, 9(5), 167-176.

xlv. Ong'ondo,C.O. (2009). Pegagogical Practice and Support of English Language Student Teacher during Practicumin KenyaPhD Thesis; University of Leeds..

xlvi. Ponterotto, J. G. (2006). Briefnote on the origins, evolution, and meaning of the qualitative research concept 'thick description'. The Qualitative Report 11 (3), 538-549.

xlvii. $\quad$ Rao.Z. (2007).Training in brainstorming and developing writing skills. ETL Journal, 61(2), 44-51.

xlviii. Reem, A.; Danyah,A.W.;Nadia, S. (2018) Teacher and Students' Perceptionson the Effectiveness of the Writing Tasksin the Foundation Year, King Abdulaziz University, Jeddah, KSA.

xlix. Richards, J. (2005). Communicative Language Teaching Today. Cambridge: Cambridge University Press.

1. Richards, J. C. (2009). Curriculum Development in Language Teaching. Cambridge: Cambridge University Press.

li. Richards, J.C (2008). Second Language Teacher Education Today. RELC Journal, Vol. 39,

lii. Santangelo, T. and Olinghouse, N. (2009) Effective Writing Instruction for Students who have Writing Difficulties. Focus on exceptional children

liii. Silverman, D. (2003). Analyzing talk and text. In N. K. Denzin and Y. S. Lincoln (Eds). Collecting and interpreting qualitative materials (pp. 340-362). London: Sage Publications, Inc.

liv. Stake, R. E. (2005). Qualitative case studies. In N. K. Denzin and Y. S. Lincoln (Eds. ), The Sage handbook of qualitative research (3`d ed. ), (pp. 443-466). London: Sage Publications Limited.

lv. Stake, R. E. (2006). Multiple case study data analysis. New York: The Guilford Press. 
lvi. Standard Digital (2014) 'Kaimenyi's speech on the release of 2013 KCSE exam results', (2014) [Online Newspaper] Available at:http://www.standardmedia.co.ke/lifestyle/article/2000105981/kaimenyi-s-speechon-therelease-of-2013-kcse-exam-results?pageNo 2

lvii. Stanley, G. (2007).Approaches to Process Writing, www.teaching-english.net/think/write/process_write.shtml

lviii. Sure, N. \& Ogechi, E. (2009). Linguistic Human Rights and Language Policy in the Kenyan Education System. Oxford, UK: African Books Collective Limited TESOL (2006). Pre-K-12 English Language Proficiency Standards, Alexandria, VA: TESOL International Association.

lix. Tangpermpoon,T (2008) Integrating Approaches To Improve Students Writing Skills for English Major Students. ABAC Journal Vol. 28, No. 2 (May-August 2008, Pp.1-9)

lx. Tribble, C. (2009). Writing. New York: Oxford University Press

lxi. What Works Clearinghouse (2012).Teaching elementary school students to be effective writers.

lxii. Williams, J. G. (2003). Providing feedback on ESL students" written assignments. The Internet TESL Journal, IX (10), 123-129

lxiii. Wragg, E.C. (2011).An Introduction to Classroom Observation. London: Routledge.

lxiv. Yasuda, S.(2011). Genre-based tasks in foreign language writing: Developing writers' genre awareness, linguistic knowledge and writing competence. Journal of Second Language Writing. 20: 111-133.

lxv. Yin, R. K. (2003). Case study research design and methods ( $3^{\text {rd }}$ ed.), London: Sage Publications 